\title{
Removal of arsenic(III) from aqueous solution using a low-cost by-product in Fe-removal plants-Fe-based backwashing sludge
}

\author{
Kun Wu ${ }^{\mathrm{a}, \mathrm{b}}$, Ruiping Liu ${ }^{\mathrm{b}, *}$, Tao $\mathrm{Li}^{\mathrm{c}}$, Huijuan Liu ${ }^{\mathrm{b}}$, Junming Peng ${ }^{\mathrm{d}}$, Jiuhui $\mathrm{Qu}^{\mathrm{b}}$ \\ a School of Environmental and Municipal Engineering, Xi'an University of Architecture and Technology, Xi'an, Shaanxi 710055, China \\ ${ }^{\mathrm{b}}$ State Key Laboratory of Environmental Aquatic Chemistry, Research Center for Eco-Environmental Sciences, P.O. Box 2871, Beijing 100085, China \\ ${ }^{\mathrm{c}}$ Research Center of Water Treatment Technology, Zhengzhou Water Supply Corporation, Zhengzhou, Henan 450007, China \\ ${ }^{\mathrm{d}}$ SIPPR Engineering Group Co., Ltd., Zhengzhou, Henan 450007, China
}

\section{H I G H L I G H T S}

- A low-cost adsorbent was obtained from backwashing sludge to remove As(III) from wastewater.

- The effective constituents for removing As(III) within FBBS are $\gamma$ $\mathrm{FeOOH}$ and $\mathrm{Fe}\left(\mathrm{SO}_{4}\right) \mathrm{OH}$.

- The kinetics data were best fitted by the Elovich and Power models due to its high heterogeneity.

- The maximum adsorption capacity of As(III) onto FBBS was as high as $59.7 \mathrm{mg} / \mathrm{g}$.

- The removal mechanisms include surface complexation, ion exchange and co-precipitation.

\section{A R T I C L E I N F O}

\section{Article history:}

Received 28 February 2013

Received in revised form 16 April 2013

Accepted 17 April 2013

Available online 29 April 2013

\section{Keywords:}

Arsenic

Adsorption

Iron

Low-cost adsorbent

Sludge
G R A P H I C A L A B S T R A C T

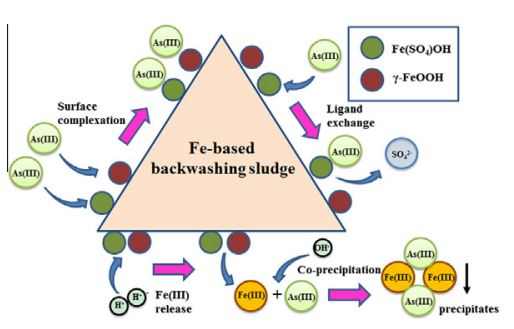

\begin{abstract}
A B S T R A C T
This study investigated the elemental composition and distribution of the Fe-based backwashing sludge (FBBS), and studied its adsorption behaviors and mechanisms towards arsenite [As(III)]. The characterization results of EDS, XPS, and XRF corroborated that the valuable constituents within FBBS are ferric oxhydroxide $(\gamma-\mathrm{FeOOH})$ and sulfate inter-layered $\mathrm{Fe}$ hydroxide $\left[\mathrm{Fe}\left(\mathrm{SO}_{4}\right) \mathrm{OH}\right]$. The zeta-potential results indicated a $\mathrm{pH}_{\mathrm{ZPC}}$ value of 7.7. The adsorption equilibrium could be reached within $18 \mathrm{~h}$, and the kinetics data were well described by the Elovich and Power models due to the heterogeneous surfaces of FBBS. The isotherm experimental results suggested that the maximum adsorption amount of As(III) was around $59.7 \mathrm{mg} / \mathrm{g}$ (initial $\mathrm{As}(\mathrm{III})=1-120 \mathrm{mg} / \mathrm{L}, \mathrm{pH}=7.0, T=25^{\circ} \mathrm{C}$ ), which is higher than most of other low-cost adsorbents. The uptake of As(III) onto FBBS would increase with an increase in temperatures, inferring that it is an endothermic process. The optimal initial solution $\mathrm{pH}$ for As(III) removal was around $\mathrm{pH}$ 8.0. The release of sulfate from FBBS after As(III) adsorption implied the occurrence of ligand exchanges, while the mechanism of Fe(III) precipitation might be also involved. The spectra of FTIR and XPS revealed that the surface hydroxyl groups played an important role in the adsorption of $\mathrm{As}(\mathrm{III})$, and the oxidation state of As(III) was not changed. Moreover, phosphates ( $>1 \mathrm{mM}$ ) could strongly inhibit the removal of As(III). The desorption results indicated that the release of As caused by alkali or phosphate eluent should be avoided for the scrutiny of waste landfill.
\end{abstract}

Crown Copyright $\odot 2013$ Published by Elsevier B.V. All rights reserved.

\footnotetext{
* Corresponding author. Tel./fax: +86 1062849160.

E-mail address: liuruiping@rcees.ac.cn (R. Liu).
} 


\section{Introduction}

Arsenic (As) pollution in soil and water systems is a global issue due to its toxicity and chronic effects on human health $[1,2]$. The discharge of untreated high-arsenic wastewater poses a serious threat to the soil and aquatic environment. Conventional or non-conventional methods for the removal of As from wastewater include chemical precipitation, oxidation, coagulation, reverse osmosis, ion exchange, adsorption, membrane filtration, foam flotation, and solvent extraction [3]. Among these technologies, adsorption is suitable to practical application in engineering due to its advantages, such as high efficiency, low cost, and easy operation. Many kinds of adsorbents are effective for As removal, including some commercially available ones-activated carbon and activated alumina. However, many of them are restricted for engineering application due to their high prices. Researchers have made efforts on the use of waste materials as low-cost adsorbents for the removal of pollutants from wastewater [4$6]$. It has been widely recognized that the reuse of a waste material as low-cost adsorbent to remove As from wastewater could not only decrease the cost of wastewater treatment, but also reduce the amounts of these solid wastes. Fly ash, originated from coal power stations, was proven to be effective for the removal of arsenate $[\mathrm{As}(\mathrm{V})]$ from water [7]. Li et al. [8] optimized an iron-oxide-containing fly ash for As removal by heating and washing the material with acid/alkali solutions, and they found that the adsorption capacity of $\mathrm{As}(\mathrm{V})$ onto the modified fly ash was significantly improved compared with that of the un-modified one. Steel industry waste, such as blast furnace slag, could be used as adsorbent for the removal of arsenite [As(III)] and the maximum adsorption amount was reported as $1.40 \mathrm{mg} / \mathrm{g}$ at the initial concentration of $1 \mathrm{mg} / \mathrm{L}$ As(III) [9]. Aluminum ( $\mathrm{Al}$ ) industry waste-red mud was also effective for the removal of both $\mathrm{As}(\mathrm{III})$ and $\mathrm{As}(\mathrm{V})[10,11]$. Li et al. [12] reported that ferrous based red mud sludge (FRS) is an attractive material for the removal of As in rural areas due to its high uptake capability, good settlement performance, and cost-effectiveness. Besides FRS, drinking-water treatment residuals (WTRs) could also be feasible adsorbents, which exhibited high affinities towards $\mathrm{As}(\mathrm{III})$ and $\mathrm{As}(\mathrm{V})$ with minimal As desorption [13]. In addition, a $\mathrm{Fe}(\mathrm{III}) /$ $\mathrm{Cr}$ (III) waste obtained from fertilizer industry could also remove As(V) effectively [14].

As stated above, we can draw the conclusion that the oxides of iron (Fe) or aluminum ( $\mathrm{Al}$ ) play an important role in the feasibility of these low-cost adsorbents for the removal of As. It is in agreement with the previous reporting [15] that both Fe and Al compounds are the most popular adsorbents being used for the removal of As from aqueous solution. Meanwhile, Bhatnagar and Sillanpää [16] stated that a suitable low-cost adsorbent should meet several requirements, including a wide applicability, high adsorption capacity/rate, high selectivity for various concentrations, and tolerance of the complexity of wastewater. Thus, there is still a need to broad the reuse of Fe-based or Al-based industrial by-products and predict their performance of the adsorption processes for the treatment of high-arsenic wastewater.

Water treatment plants for Fe (mainly Fe(II)) removal using the direct filtration process can produce a considerable amount of backwashing water, equivalent to about $3-4 \%$ of the amount of water treated [17]. The major component within the solid precipitates is Fe hydroxide, which quantity is depending on the manufacturing conditions [17]. Fe-based backwashing sludge (FBBS) has been proven to be an effective adsorbent for arsenate $[\mathrm{As}(\mathrm{V})]$ [18]. As(III) is more mobile [19], more toxic [20], and more difficult to remove [21] than $\mathrm{As}(\mathrm{V})$ at neutral $\mathrm{pH}$ conditions. However, the reuse potential of FBBS for the removal of $\mathrm{As}(\mathrm{III})$ remains to be investigated.
Considering these backgrounds, this study focuses on the adsorption behaviors and mechanisms of As(III) onto FBBS. The elemental composition and distribution on the surfaces of FBBS were studied using several characterization methods. Batch experiments were conducted to investigate the kinetics and isotherm characteristics of As(III) adsorption onto FBBS. The influences of operational or water quality parameters on the removal of As(III) were also studied, including adsorbent dosages, solution $\mathrm{pH}$, and coexisting anions. Finally, the desorption experiments were performed to assess the disposal safety of As-loaded FBBS.

\section{Experimental}

\subsection{Materials and the preparation of adsorbent}

All chemicals were of analytical grade and purchased from Beijing Chemical Co. All solutions were prepared with deionized water. The As(III) stock solution was prepared with sodium arsenite $\left(\mathrm{NaAsO}_{2}\right)$. Sodium nitrate $\left(\mathrm{NaNO}_{3}\right)$ was used to fix a constant ion strength $\left(0.01 \mathrm{M} \mathrm{NaNO}_{3}\right)$ of solutions. Additionally, sodium hydroxide $(\mathrm{NaOH})$ and hydrochloric acid $(\mathrm{HCl})$ with concentrations of $0.01 \mathrm{M}, 0.1 \mathrm{M}$, and $1 \mathrm{M}$ were used to adjust $\mathrm{pH}$ of solutions. FBBS was taken from a groundwater treatment plant in which the process of aeration with subsequent direction filtration is used for the removal of extra iron and manganese in groundwater. The major water quality parameters were listed in Table S1. FBBS was taken as slurry from the thickener of the backwashing under flow, filtered with filter paper, air-dried under $60^{\circ} \mathrm{C}$ for $24 \mathrm{~h}$ and $100{ }^{\circ} \mathrm{C}$ for $12 \mathrm{~h}$. After that, it was crushed and sieved to obtain a particle size under $60 \mu \mathrm{m}$ (Fig. S1). Finally, the adsorbent was stored in a desiccator for use.

\subsection{Batch adsorption experiments}

\subsubsection{Kinetics and isotherms}

For kinetics experiments, $0.96 \mathrm{~g}$ FBBS was added into $1600 \mathrm{~mL}$ of $\mathrm{As}(\mathrm{III})$ solution with $5 \mathrm{mg} / \mathrm{L} \mathrm{As}(\mathrm{III})$ and an ionic strength of $0.01 \mathrm{M} \mathrm{NaNO}_{3}$. Samples were taken at different time intervals and filtered with a $0.45 \mu \mathrm{m}$ polycarbonate filter membrane. The next experiments were all conducted at $25 \pm 0.1^{\circ} \mathrm{C}$ on a mechanical orbit shaker at $170 \mathrm{rpm}$ for $24 \mathrm{~h}$. In the sorption isotherm study, $0.06 \mathrm{~g}$ FBBS were respectively added into $100 \mathrm{~mL}$ of $\mathrm{As}$ (III) solution with different initial concentrations (from $1 \mathrm{mg} / \mathrm{L}$ to $120 \mathrm{mg} / \mathrm{L}$ ) and a constant ionic strength of $0.01 \mathrm{M} \mathrm{NaNO}_{3}$. The samples were taken after $24 \mathrm{~h}$ of contact and filtered. In the aforementioned experiments, solution $\mathrm{pH}$ was maintained at $\mathrm{pH} 7.0 \pm 0.2$ using solutions of $\mathrm{HCl}(0.01-0.1 \mathrm{M})$ and $\mathrm{NaOH}(0.01-0.1 \mathrm{M})$.

\subsubsection{Influences of $\mathrm{pH}$, adsorbent dosage, and coexisting anions}

To investigate the influence of initial solution $\mathrm{pH}$ on the $\mathrm{As}(\mathrm{III})$ adsorption, $0.06 \mathrm{~g}$ FBBS was added into $100 \mathrm{~mL}$ of As(III) solution with a concentration of $5 \mathrm{mg} / \mathrm{L}$. The initial $\mathrm{pH}$ of the solutions varied from 4.0 to 10.0 by adding $0.1 \mathrm{M} \mathrm{HCl}$ and $0.1 \mathrm{M} \mathrm{NaOH}$. To investigate the $\mathrm{pH}$ variation after the adsorption of $\mathrm{As}(\mathrm{III})$, the solution $\mathrm{pH}$ was not maintained during the adsorption process and detected after $24 \mathrm{~h}$ of adsorption. To determine the effects of FBBS dosages on the removal of As(III), varying amounts of FBBS (from $0.02 \mathrm{~g}$ to $1.0 \mathrm{~g}$ ) was added into a group of conical flasks which contained $100 \mathrm{~mL}$ of As(III) solution with an initial concentration of $5 \mathrm{mg} / \mathrm{L}$. To study the effects of coexisting anions, $100 \mathrm{~mL}$ of $5 \mathrm{mg} / \mathrm{L} \mathrm{As}$ (III) solutions with four different anions (chloride ion, carbonate, phosphate, and sulfate) were prepared in flasks. A series of concentrations of coexisting anions $(0,1$, and $10 \mathrm{mM})$ and an adsorbent dosage of $6.0 \mathrm{~g} / \mathrm{L}$ were employed. During the experiments to study the effects of FBBS dosage or coexisting anions, the solution $\mathrm{pH}$ and 
ionic strength were controlled at $7.0 \pm 0.2$ and $0.01 \mathrm{M} \mathrm{NaNO}_{3}$, respectively.

\subsubsection{Desorption}

For desorption studies, the residual solids retained on the filter membrane were collected and dried after the filtration of the suspension from adsorption tests. The spent FBBS after As(III) adsorption (load amount of $\mathrm{As}(\mathrm{III})=7.7 \mathrm{mg} / \mathrm{g}$ ) was tested with toxicity characteristic leaching procedure (TCLP) designed by USEPA to determine it as inert or hazardous in terms of the leachability of adsorbed As [22]. Moreover, to evaluate the pH effects, $0.06 \mathrm{~g}$ Asloaded FBBS was added into each $150 \mathrm{~mL}$ flask containing $100 \mathrm{~mL}$ solution under different $\mathrm{pH}$ conditions $(\mathrm{pH}=3.0-12.0) . \mathrm{NaNO}_{3}$ was added to $0.01 \mathrm{M}$ to adjust the ionic strength of the solution. The flask was then shaken at $170 \mathrm{rpm}$ for $24 \mathrm{~h}$ at $25 \pm 1{ }^{\circ} \mathrm{C}$. The suspension solution was filtered and analyzed for desorbed As in a similar way as described previously. To investigate the As released caused by phosphate solutions, $0.06 \mathrm{~g}$ As-loaded sludge was added into each $150 \mathrm{~mL}$ flask containing $100 \mathrm{~mL}$ solution with different phosphate concentrations (from 0.01 to $0.1 \mathrm{M}$ ). Other procedures were the same as those in the above experiments.

\subsection{Analytical methods and characterizations}

Total arsenic $(\mathrm{As}(\mathrm{tot})=\mathrm{As}(\mathrm{III})+\mathrm{As}(\mathrm{V}))$, total iron $[\mathrm{Fe}($ tot $)]$, and total phosphorus $[\mathrm{P}($ tot $)]$ concentrations were determined using an ICP-OES (SCIEX Perkin Elmer Elan mode 5000, USA). As(III) analysis was conducted using spectroscopy equipment (AF-610A, Beijing Ruili Analytical Instrument Co., Ltd. China) on the basis of hydride generation atomic fluorescence spectrometry (HG-AFS). Sulfate anions were determined by ion chromatograph (Dionex 2000, USA). Prior to analysis, the aqueous samples were acidified with $1 \% \mathrm{HNO}_{3}$ and stored in acid-washed glassware vessels.

The samples were analyzed using a scanning electron microscope (SEM) with an Energy Dispersive Spectrometer (EDS) KEVEX level 4 (Hitachi S-3500N, Japan). X-ray photoelectron spectroscopy (XPS) data were collected on an ESCA-lab-220i-XL spectrometer (Shimadzu, Japan) with monochromatic $\mathrm{Al} \mathrm{K \alpha}$ radiation $(1486.4 \mathrm{eV})$. The composition concentrations of the samples were determined by an AXIOS pw4400 X Ray Fluorescence (XRF) analyzer operating at $4 \mathrm{~kW}$ with $\mathrm{Rh}$ Ka used as X-ray source. Samples for Fourier Transform infrared spectroscopy (FTIR) determination were ground with spectral grade potassium bromide $(\mathrm{KBr})$ ( $10 \mathrm{mg}$ adsorbent with $250 \mathrm{mg} \mathrm{KBr}$ ) in an agate mortar. A zeta potential analyzer (Zetasizer 2000, Malvern, UK) was used to analyze the zeta potential of FBBS. An acid digestion method [23] was applied to measure the amounts of Fe and Mn content within FBBS.

\section{Results and discussion}

\subsection{FBBS characterization}

In previous studies, the analysis results of BET, SEM, and XRD indicated that FBBS had a large BET surface area of $151.9 \pm 3.5 \mathrm{~m}^{2} / \mathrm{g}$ (Table S2) due to its rough surfaces with plentiful aggregated small particles, and it contained sulfate inter-layered Fe hydroxide $\left[\mathrm{Fe}\left(\mathrm{SO}_{4}\right) \mathrm{OH}\right]$, lepidocrocite $(\gamma-\mathrm{FeOOH})$, quartz $\left(\mathrm{SiO}_{2}\right)$, and calcium carbonate $\left(\mathrm{CaCO}_{3}\right)$ [18]. Glotch and Kraft [24] stated that the formation of $\gamma$-FeOOH can be favored by several factors, including a slow rate of $\mathrm{Fe}^{3+}$ hydrolysis, a low effective pressure of $\mathrm{CO}_{2}$, or the presence of excess $\mathrm{Fe}^{2+}$ in solution. These factors were in accordance with the system conditions of aeration-direct filtration for removing extra Fe(II) from groundwater. Table 1 shows the element contents on the surfaces of FBBS using different analysis methods. The EDS results indicated that the weight ratio
Table 1

The major element contents within FBBS.

\begin{tabular}{lllll}
\hline \multirow{2}{*}{ Elements } & \multicolumn{4}{l}{ Analysis methods } \\
\cline { 2 - 5 } & EDS (wt.\%) & XPS (wt.\%) & XRF (wt.\%) & Acid digestion (mg/L) \\
\hline $\mathrm{Fe}$ & 31.5 & 18.32 & 22.0 & 279.9 \\
$\mathrm{Mn}$ & 2.15 & 0.26 & 2.64 & 32.4 \\
$\mathrm{Si}$ & 4.3 & 1.64 & 2.8 & - \\
$\mathrm{Ca}$ & 4.7 & 1.26 & 3.33 & - \\
$\mathrm{S}$ & $\mathrm{N} . A$. & 0.13 & 0.04 & - \\
$\mathrm{P}$ & N.A. & 1.37 & 1.28 & - \\
$\mathrm{O}$ & 22.5 & 39.67 & N.A. & - \\
\hline
\end{tabular}

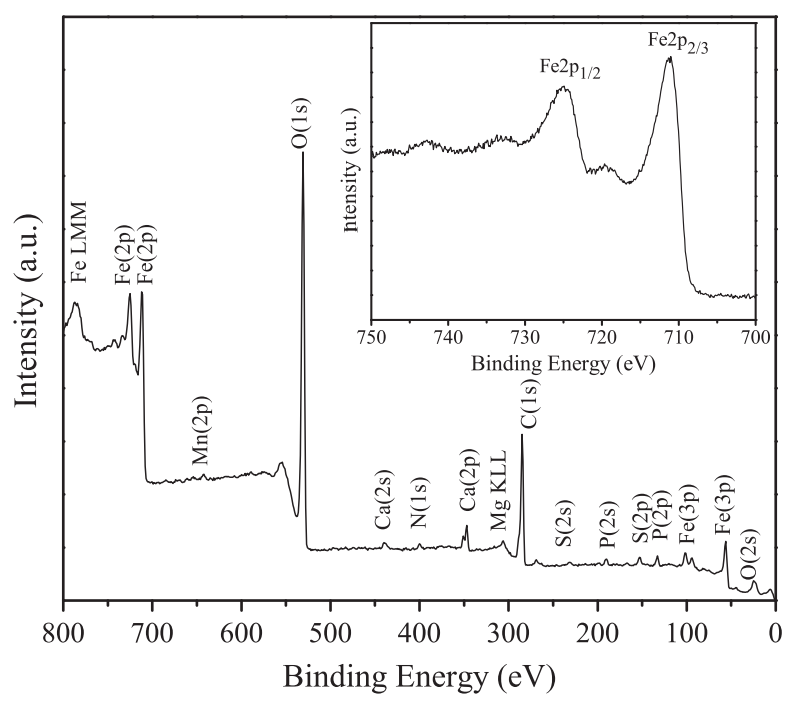

Fig. 1. XPS wide scan spectrum and Fe2p spectrum of fresh FBBS.

of Fe element was close to 30\% within FBBS. Comparatively, the molar ratio of $\mathrm{Mn}$ on the surface of FBBS was only around $2 \%$. Fig. 1 presents the wide scan XPS spectrum of FBBS, suggesting that the presences of Fe, $\mathrm{Mn}, \mathrm{Ca}, \mathrm{Mg}, \mathrm{S}, \mathrm{P}, \mathrm{N}$, and $\mathrm{O}$ within the adsorbent. The XPS spectrum of Fe2p was around $711.5 \mathrm{eV}$, inferring that $\gamma$ $\mathrm{FeOOH}$ dominated the oxidation state of iron oxides within FBBS [25]. According to the XPS results, the Fe content in FBBS was much higher than the other elements (Table 1). The results of XRF also implied that FBBS was mainly comprised with the oxides of Fe, whereas the content of $\mathrm{Mn}$ was negligible (Table 1). All these results corroborated that Fe oxides were the most important components within FBBS. As the aforementioned methods are utilized for the analysis of elemental contents on the surfaces of samples, the difference in their results might be mainly due to the heterogeneous surfaces of FBBS. Thus, acid digestion was performed to obtain a more accurate analysis of the Fe level within FBBS (Table 1), which determined that the content of Fe was around $279.9 \mathrm{mg} / \mathrm{g}$.

\subsection{Adsorption kinetics}

Fig. 2 demonstrates the kinetics characteristics of As(III) adsorption onto FBBS with an initial $\mathrm{As}(\mathrm{III})$ concentration of $5 \mathrm{mg} / \mathrm{L}$ at $\mathrm{pH}=7.0$. The uptake of $\mathrm{As}(\mathrm{III})$ increased rapidly in the first $1 \mathrm{~h}$, and the curve started to flatten out thereafter due to a much slower rate. This growth trend for adsorbed As(III) amounts was similar with that of $\mathrm{As}(\mathrm{V})$ adsorbed by the same adsorbent [18]. The equilibrium adsorption amount was around $7.0 \mathrm{mg} / \mathrm{g}$, which could be achieved after $18 \mathrm{~h}$ contact time. The equilibrium time of $\mathrm{As}$ (III) is close to that of $\mathrm{As}(\mathrm{V})(16.67 \mathrm{~h})$ [18]. We found a release of the sulfate during the adsorption, which reached the peak value in a 

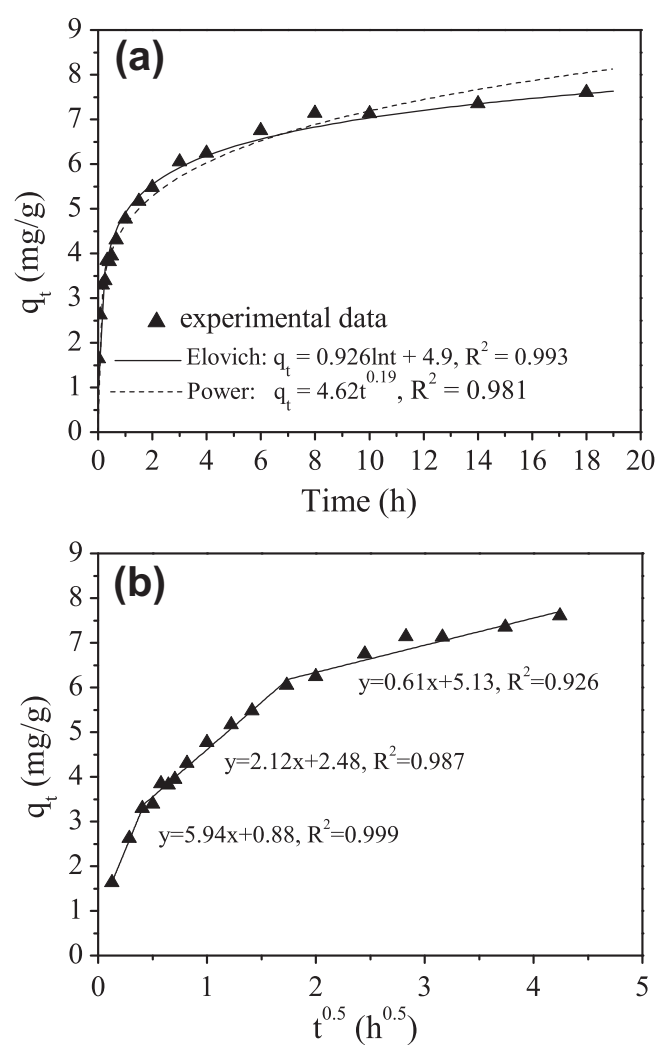

Fig. 2. Adsorption kinetics of $\mathrm{As}(\mathrm{III})$ adsorption by FBBS, the data were fitted with (a) the Elovich and Power models and (b) the intra-particle diffusion model. (Experimental conditions: initial $\mathrm{As}(\mathrm{III})=5 \mathrm{mg} / \mathrm{L}$, adsorbent dosage $=0.6 \mathrm{~g} / \mathrm{L}$, $\mathrm{pH}=7.0$, ion strength $=0.01 \mathrm{M} \mathrm{NaNO}_{3}$, agitation speed $=170 \mathrm{rpm}$, reaction time $=24$ h.)

short time of about $2 \mathrm{~h}$ (Fig. S2). Thus, it is indicated the ligand exchange with sulfate, which we will explain later, might be involved in the initial stage of the adsorption of As(III). Additionally, the concentrations of $\mathrm{As}(\mathrm{V})$, which were calculated by subtracting As(III) from As(tot), were consistently below $20 \mu \mathrm{g} / \mathrm{L}$ during the adsorption process (data not shown), and this indicated the transformation of $\mathrm{As}(\mathrm{III})-\mathrm{As}(\mathrm{V})$ was negligible during the adsorption process. To further understand the kinetics characteristics, several adsorption kinetics models were utilized to fit the kinetics data. As the pseudo-first-order and pseudo-second-order models did not fit well to the data (results not shown), three other kinetics models were performed as follows, (Eqs. (1)-(3)) [26-28]:

$q_{t}=k_{i d} t^{0.5}+C$ intra-particle diffusion model

$q_{t}=\frac{1}{\beta} \ln t+\frac{1}{\beta} \ln (\alpha \beta) \quad$ Elovich model

$\ln q_{t}=\ln \left(k q_{e}\right)+\frac{1}{m} \ln t \quad$ Power model

where $t$ is the contact time of adsorption experiment (h); $q_{e}(\mathrm{mg} / \mathrm{g})$ and $q_{t}(\mathrm{mg} / \mathrm{g})$ are respectively the adsorption capacity at equilibrium and at any time $t ; \alpha$ is the initial sorption rate $(\mathrm{mg} / \mathrm{g} \mathrm{h}), \beta$ is the desorption constant $(\mathrm{g} / \mathrm{mg}) ; 1 / m$ is the order for the adsorption process, $k$ and $k_{i d}\left(\mathrm{mg} / \mathrm{g} \mathrm{h}^{0.5}\right)$ are the rate constants for these models, respectively. The parameters of these kinetics models are listed in Table S3.

According to the intra-particle diffusion model, the adsorption process could be divided into three time sections ( $0 \mathrm{~min}<-$ $t<10 \mathrm{~min}, 10 \mathrm{~min}<t<3 \mathrm{~h}$, and $3 \mathrm{~h}<t<18 \mathrm{~h}$ ) (Fig. 2b). An adsorp- tion process is normally controlled by three steps, including (1) bulk and film boundary diffusion, (2) intra-particle diffusion, and (3) the reactions of physical/chemical binding at active sites. In this study, the first adsorption stage was achieved within $10 \mathrm{~min}$, and this implied the fast penetration rate of As anions/molecules into FBBS, as being similar with the synthesized Fe-Mn binary oxide towards As [29]. As the fit of the kinetics data to the intra-particle diffusion model did not show a good linear relationship with a straight line passing through the origin point, it is indicated that particle diffusion might not be the rate-limiting mechanism [30]. This phenomenon is similar with the adsorption performance of other pollutants (i.e. phosphate or dyes) onto Fe-based sludge [6,31]. Moreover, the $R^{2}$ results implied the adsorption kinetics of As(III) on FBBS can be satisfactorily described by either the Elovich model or the Power model. These two kinetics models have been proven to be suitable for the heterogeneous systems [26], which might exhibit different activation energies for the chemisorption on its surfaces.

\subsection{Adsorption isotherms}

Fig. 3 shows the adsorption isotherm of As(III) onto FBBS, which is crucial to understand the interaction between an adsorbate and an adsorbent. To provide quantitative information, these data were respectively fitted by the Langmuir and Freundlich isotherm models [32,33]:

$q_{e}=\frac{q_{m} b C_{e}}{1+b C_{e}} \quad$ Langmuir model

$q_{e}=K_{F} C_{e}^{\frac{1}{n}} \quad$ Freundlich model

where $C_{e}$ is the As concentration in the solution $(\mathrm{mg} / \mathrm{L}), q_{e}$ is the As concentration in the solid adsorbent $(\mathrm{mg} / \mathrm{g}), q_{m}$ is the maximum adsorption capacity $(\mathrm{mg} / \mathrm{g}), K_{F}$ is a constant related to the adsorption capacity $\left(\mathrm{mg}^{1-1 / n} \mathrm{~L}^{1 / n} / \mathrm{g}\right), b$ is a constant related to the energy of adsorption $(\mathrm{L} / \mathrm{g}), n$ is a constant related to the energy of adsorption. The parameters of the two isotherm models are shown in Table S4.

The Langmuir isotherm represents the monolayer coverage adsorption model, and the fitted $q_{m}$ values of As(III) by FBBS were

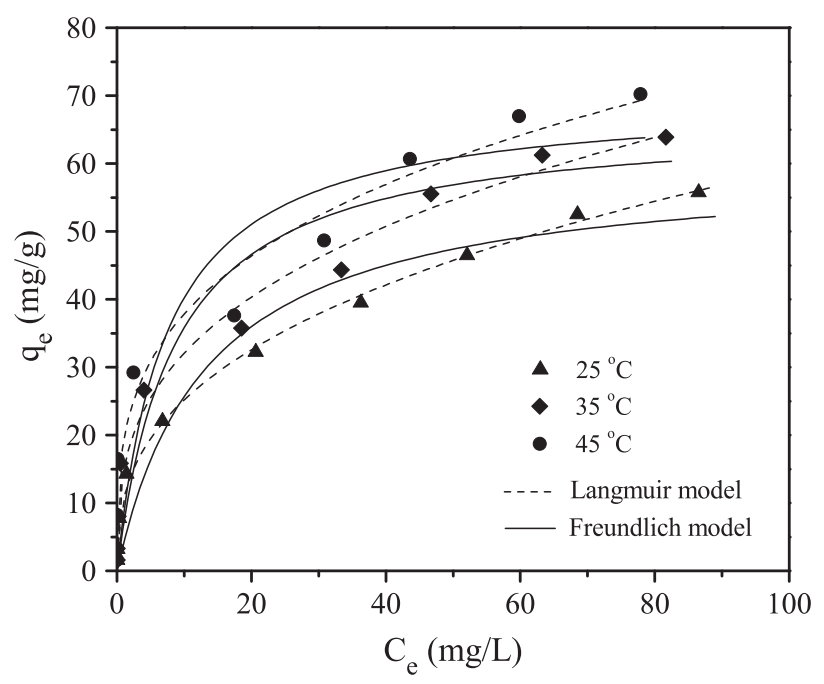

Fig. 3. Adsorption isotherms of As(III) adsorption by FBBS. Symbols indicate experimental data; dashed lines represent the Langmuir model; solid lines refer to the Freundlich model. (Experimental conditions: adsorbent dosage $=0.6 \mathrm{~g} / \mathrm{L}$, $\mathrm{pH}=7.0$, ion strength $=0.01 \mathrm{M} \mathrm{NaNO}_{3}$, agitation speed $=170 \mathrm{rpm}, \mathrm{T}=25 \pm 1^{\circ} \mathrm{C}$ reaction time $=24 \mathrm{~h}$.) 
Table 2

Comparison of maximum As(III) adsorption capacities between FBBS and other waste adsorbents.

\begin{tabular}{|c|c|c|c|c|}
\hline Adsorbent & $\begin{array}{l}\text { Max. As(III) adsorption } \\
\text { capacity }(\mathrm{mg} / \mathrm{g})\end{array}$ & $\mathrm{pH}$ & Effective components & References \\
\hline FBBS & 59.7 & 7.0 & $\mathrm{Fe}\left(\mathrm{SO}_{4}\right) \mathrm{OH}, \gamma-\mathrm{FeOOH}$ & This study \\
\hline Blast furnace slag & 1.4 & 12 & $\mathrm{Fe}_{2} \mathrm{O}_{3}$ & [9] \\
\hline Ferrous based red mud & 0.9 & 7.25 & $\mathrm{Fe}_{2} \mathrm{O}_{3}, \mathrm{Al}_{2} \mathrm{O}_{3}$ & [12] \\
\hline WTRs & 15 & $6.0-6.5$ & Amorphous $\mathrm{Al} / \mathrm{Fe}$ oxide & [13] \\
\hline Reused sanding wastes & 12.5 & 8 & $\alpha$-Alumina & [35] \\
\hline
\end{tabular}

calculated to be $59.7 \mathrm{mg} / \mathrm{g}$ at $\mathrm{T}=25{ }^{\circ} \mathrm{C}$, which was higher than that of $\mathrm{As}(\mathrm{V})(43.2 \mathrm{mg} / \mathrm{g})$ under the same experimental conditions [18]. The comparison of $R^{2}$ indicated that the Freundlich model was better than the Langmuir model to describe the adsorption of As(III) onto FBBS (Table S4). It is in agreement with the reporting of $\mathrm{Li}$ et al., who stated that the Freundlich isotherm model can be better applied to adsorption processes on heterogeneous surfaces than the Langmuir model [34]. Meanwhile, the maximum uptake of As(III) increased from $59.7 \mathrm{mg} / \mathrm{g}$ to $69.8 \mathrm{mg} / \mathrm{g}$ with temperatures increasing from $25^{\circ} \mathrm{C}$ to $45^{\circ} \mathrm{C}$ (Table S4). It is indicated that the adsorption of As(III) by FBBS is an endothermic process, which is also similar with that of $\mathrm{As}(\mathrm{V})[18]$. Generally, comparisons of maximum adsorption capacity between different adsorbents are difficult to make due to the variability in experimental parameters utilized. The values of $q_{\mathrm{e}-\mathrm{As} \text { (III) }}$ of FBBS and some other waste materials are listed in Table 2, which illustrates that FBBS exhibited a remarkable adsorption capacity towards As(III) as a low-cost adsorbent

\subsection{Effects of solution $\mathrm{pH}$ on $\mathrm{As}(\mathrm{III})$ adsorption}

Fig. S3 shows the variations in zeta potential of FBBS before and after reaction with $\mathrm{As}(\mathrm{III})$ at $\mathrm{pH} 3.0-10.0$, indicating that the $\mathrm{pH}$ of zero point charge $\left(\mathrm{pH}_{\mathrm{ZPC}}\right)$ of FBBS was around 7.7. Thus, the protonation reactions would occur at $\mathrm{pH}<7.7$. It can be observed in Fig. 4a and Fig. S4 that the equilibrium solution $\mathrm{pH}$ shifted to the $\mathrm{pH}_{\mathrm{ZPC}}$ value after the adsorption of $\mathrm{As}(\mathrm{III})$ or $\mathrm{As}(\mathrm{V})$, as being in accordance with the protonation and the deprotonation reactions (Eqs. (6)-(9)). The surface characteristics of FBBS could enable it as a good neutralizing agent for the treatment of acidic high-arsenic wastewater. Fig. $4 \mathrm{a}$ also presents that the removal efficiency of As(III) decreased as $\mathrm{pH}$ increasing from 4 to 6 . After that, the uptake of $\mathrm{As}(\mathrm{III})$ increased within the elevated $\mathrm{pH}$ and reached the maximum value of $7.7 \mathrm{mg} / \mathrm{g}$ at initial $\mathrm{pH}$ of 8 . The further increase of $\mathrm{pH}$ led to the decreased effectiveness of As(III) removal, which was calculated to be $71.6 \%$ and $54.6 \%$ at $\mathrm{pH} 9$ and $\mathrm{pH} 10$. Contractively, the removal of $\mathrm{As}(\mathrm{V})$ by FBBS was consistently decreased with $\mathrm{pH}$ increasing from 4 to 10 under the same experimental conditions (Fig. S4). The adsorption of As(III) by FBBS at above pH 6 was similar with that by the pure Fe oxide, in which the uptake of $\mathrm{As}(\mathrm{III})$ increased gradually with the elevated $\mathrm{pH}$ and reached the maximum value at $\mathrm{pH}$ close to 8.8 [36]. $\mathrm{p} K_{\mathrm{a}}^{1}$ value of $\mathrm{H}_{3} \mathrm{AsO}_{3}$ is 9.2, indicating that $\mathrm{As}(\mathrm{III})$ exists as neutral species at $\mathrm{pH}<9.2$ and as anions at $\mathrm{pH}>9.2$. Hence, the decreased effectiveness of As(III) removal at high $\mathrm{pH}$ conditions could be attributed to the electrical repulsion force between FBBS and As(III) anions (Eqs. (10), (11), (14), and (15)). At pH < 9.0, the adsorption of As(III) onto hydrous iron oxide of FBBS surface is mainly by ligand exchange (Eqs. (12), (13), (16), and (17)) while electrostatic interaction is insignificant [37].

$$
\begin{aligned}
& \equiv \mathrm{FeOOH}+\mathrm{H}^{+} \Rightarrow \equiv \mathrm{FeOOH}_{2}^{+} \\
& \equiv \mathrm{FeOOH} \Rightarrow \equiv \mathrm{FeOO}^{-}+\mathrm{H}^{+} \\
& \equiv \mathrm{Fe}\left(\mathrm{SO}_{4}\right) \mathrm{OH}+\mathrm{H}^{+} \Rightarrow \equiv \mathrm{Fe}\left(\mathrm{SO}_{4}\right) \mathrm{OH}_{2}^{+}
\end{aligned}
$$

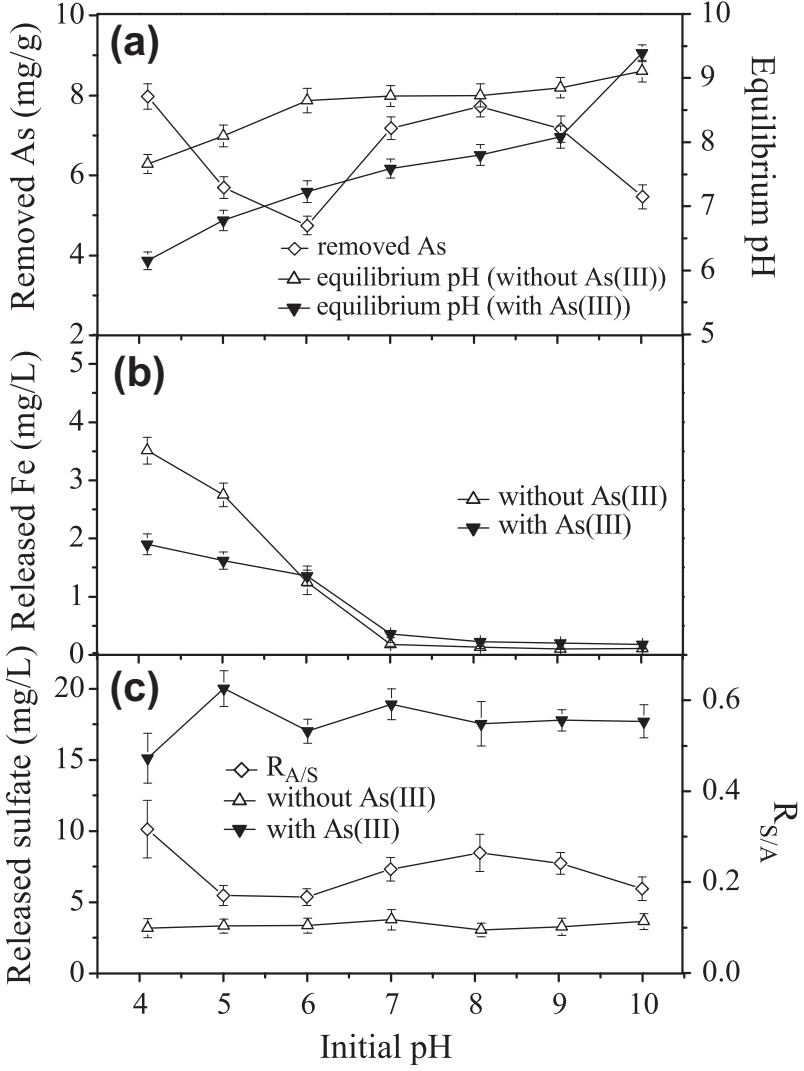

Fig. 4. Effects of initial solution $\mathrm{pH}$ on the removal of $\mathrm{As}(\mathrm{III})$, the dissolution of soluble $\mathrm{Fe}(\mathrm{III})$ speciation, and the release of sulfate. (Experimental conditions: initial $\mathrm{As}(\mathrm{III})=5 \mathrm{mg} / \mathrm{L}$, adsorbent dosage $=0.6 \mathrm{~g} / \mathrm{L}$, ion strength $=0.01 \mathrm{M} \mathrm{NaNO}_{3}$, agitation speed $=170 \mathrm{rpm}, \mathrm{T}=25 \pm 1^{\circ} \mathrm{C}$, reaction time $=24 \mathrm{~h}$.)

$\equiv \mathrm{Fe}\left(\mathrm{SO}_{4}\right) \mathrm{OH} \Rightarrow \equiv \mathrm{Fe}\left(\mathrm{SO}_{4}\right) \mathrm{O}^{-}+\mathrm{H}^{+}$

$\equiv \mathrm{FeOO}^{-}+\mathrm{H}_{2} \mathrm{AsO}_{3}^{-} \Rightarrow \equiv \mathrm{FeOHAsO}_{3}^{-}+\mathrm{OH}^{-}$

$\equiv \mathrm{FeOO}^{-}+\mathrm{HAsO}_{3}^{2-} \Rightarrow \equiv \mathrm{FeOAsO}_{3}^{2-}+\mathrm{OH}^{-}$

$\equiv \mathrm{FeOOH}_{2}^{+}+\mathrm{H}_{3} \mathrm{AsO}_{3} \Rightarrow \equiv \mathrm{FeOH}_{2} \mathrm{AsO}_{3}+\mathrm{H}_{2} \mathrm{O}+\mathrm{H}^{+}$

$\equiv \mathrm{FeOOH}+\mathrm{H}_{3} \mathrm{AsO}_{3} \Rightarrow \equiv \mathrm{FeOH}_{2} \mathrm{AsO}_{3}+\mathrm{H}_{2} \mathrm{O}$

$\equiv \mathrm{Fe}\left(\mathrm{SO}_{4}\right) \mathrm{O}^{-}+\mathrm{H}_{2} \mathrm{AsO}_{3}^{-} \Rightarrow \equiv \mathrm{Fe}\left(\mathrm{SO}_{4}\right) \mathrm{HAsO}_{3}^{-}+\mathrm{OH}^{-}$

$\equiv \mathrm{Fe}\left(\mathrm{SO}_{4}\right) \mathrm{O}^{-}+\mathrm{HAsO}_{3}^{-} \Rightarrow \equiv \mathrm{Fe}\left(\mathrm{SO}_{4}\right) \mathrm{AsO}_{3}^{2-}+\mathrm{OH}^{-}$

$\equiv \mathrm{Fe}\left(\mathrm{SO}_{4}\right) \mathrm{OH}_{2}^{+}+\mathrm{H}_{3} \mathrm{AsO}_{3} \Rightarrow \equiv \mathrm{Fe}\left(\mathrm{SO}_{4}\right) \mathrm{H}_{2} \mathrm{AsO}_{3}+\mathrm{H}_{2} \mathrm{O}+\mathrm{H}^{+}$

$\equiv \mathrm{Fe}\left(\mathrm{SO}_{4}\right) \mathrm{OH}+\mathrm{H}_{3} \mathrm{AsO}_{3} \Rightarrow \equiv \mathrm{Fe}\left(\mathrm{SO}_{4}\right) \mathrm{H}_{2} \mathrm{AsO}_{3}+\mathrm{H}_{2} \mathrm{O}$

Paven et al. stated that the As(III) removal by pure iron hydroxide $(\mathrm{FeOOH})$ was increased with an increase in $\mathrm{pH}$ at $\mathrm{pH}<6[38]$. The difference in the $\mathrm{pH}$ dependence between FBBS and $\mathrm{FeOOH}$ 
for $\mathrm{As}$ (III) removal at $\mathrm{pH}<6$ indicated that other reactions might occur between FBBS and As(III). Zhang and Itoh [39] stated that the As removal may be achieved by the reaction with metallic elements initially contained in the adsorbent. Fig. $4 \mathrm{~b}$ indicates the occurrence of Fe releasing from FBBS in the $\mathrm{pH}$ range from 4 to 6 . The fast precipitation of released Fe(III) speciation might occur (Eqs. (18)-(20)) and led to the improvement of As(III) removal at low $\mathrm{pH}$ conditions, which could account for the difference in the removal of $\mathrm{As}$ (III) by FBBS below $\mathrm{pH} 6.0$ from that by amorphous Fe oxide [40]. The concentrations of released Fe were reduced to as low as $0.18 \mathrm{mg} / \mathrm{L}$ with $\mathrm{pH}$ increased to 7 . It is inferred the surface precipitation effects would become insignificant at $\mathrm{pH}$ above 8 . That is to say, the Fe(III) precipitation favored the removal of $\mathrm{As}(\mathrm{III})$ by FBBS in the $\mathrm{pH}$ range from 4 to 6 , which resulted in the different behaviors of $\mathrm{pH}$ affecting the adsorption of $\mathrm{As}$ (III) onto FBBS and amorphous Fe oxide [38].

$$
\begin{aligned}
& \equiv \mathrm{FeOOH}+2 \mathrm{H}^{+} \Rightarrow \equiv \mathrm{FeOH}^{2+}+\mathrm{H}_{2} \mathrm{O} \\
& \equiv \mathrm{FeOOH}+\mathrm{H}^{+} \Rightarrow \equiv \mathrm{FeOOH}_{2}^{+}
\end{aligned}
$$

$\equiv \mathrm{FeOH}^{2+}+\mathrm{H}_{3} \mathrm{AsO}_{3} \Rightarrow \equiv \mathrm{FeH}_{2} \mathrm{AsO}_{3}^{2+}+\mathrm{H}_{2} \mathrm{O}$

On the other hand, the release of sulfate $\left(\mathrm{SO}_{4}^{2-}\right)$ from FBBS was strongly enhanced due to the adsorption of $\mathrm{As}(\mathrm{III})$ in the whole $\mathrm{pH}$ range of 4-10 (Fig. 4c). This implied the occurrence of the ligand exchange reactions between $\mathrm{SO}_{4}^{2-}$ and $\mathrm{As}(\mathrm{III})$, which was also observed in the process of As(III) adsorption onto another sulfatecontaining Fe oxide-schwertmannite [41]. Similarly, the release of sulfate and Fe was also detected in the adsorption of $\mathrm{As}(\mathrm{V})$ under varying $\mathrm{pH}$ conditions (data not shown). The molar ratios of the released sulfate to the adsorbed As(III) by FBBS, which could be defined as the $\mathrm{As}(\mathrm{III}) /$ sulfate exchange coefficients $\left(R_{\mathrm{As} / \mathrm{SO} 4}\right)$, varied from 0.16 to 0.31 accordingly. Liao et al. [42] stated that both the surface-adsorbed $\mathrm{SO}_{4}^{2-}$ and the ones occupying the tunnels in schwertmannite could participate in the ligand exchange reactions with As(III) onto schwertmannite. In this study, EDS and XRF results indicated the negligible content of sulfur $(S)$ on the surfaces of FBBS. Thus, it is suggested that the sulfate within FBBS were almost tunnel ones rather than surface-adsorbed ones. Burton et al. [41] studied the adsorption behaviors of As(III) by schwertmannite, and found the corresponding $R_{\mathrm{As} / \mathrm{SO} 4}$ values ranged from 0.11 to 0.25 . They also stated that the observed $\mathrm{As}(\mathrm{III}) / \mathrm{SO}_{4}^{2-}$ exchange may have occurred primarily within the schwertmannite structure, rather than at the surface sites. In this study, the values of $R_{\mathrm{As} / \mathrm{SO} 4}$ (0.16-0.31) did not have a large difference with that of the schwertmannite. Thus, it is inferred that the release mechanism of sulfate from FBBS might be similar with that of schwertmannite, which could be partly due to the predominant existence of sulfates as tunnel ones within both the two adsorbents. Due to the occurrence of ligand exchange between As(III) molecules and tunnel $\mathrm{SO}_{4}^{2-}$ (Eqs. (21)-(25)), it is suggested that the sorption process of As(III) was completed via incorporation into the FBBS structure, rather than merely through surface complexation at the solidwater interface. It is noted that there is no limit for Fe or sulfate in the discharge standards of pollutants for municipal wastewater treatment plants in China (GB18918-2002). Meanwhile, the released phosphate (data not shown) was consistently less than $0.5 \mathrm{mg} / \mathrm{L}$ as $\mathrm{P}$ (tot) under various $\mathrm{pH}$ conditions, which could meet the same discharge standards. Hence, if the high-arsenic wastewater is not treated for the purpose of reuse, the residual contents of $\mathrm{Fe}, \mathrm{P}$, and sulfate caused by FBBS could be acceptable. That is to say, FBBS will not produce a secondary pollution to the treated wastewater.

$\equiv \mathrm{Fe}\left(\mathrm{SO}_{4}\right) \mathrm{OH}+2 \mathrm{H}^{+} \Rightarrow \equiv \mathrm{Fe}\left(\mathrm{SO}_{4}\right) \mathrm{H}^{2+}+\mathrm{H}_{2} \mathrm{O}$

$$
\begin{aligned}
& \equiv \mathrm{Fe}\left(\mathrm{SO}_{4}\right) \mathrm{OH}+\mathrm{H}^{+} \Rightarrow \equiv \mathrm{Fe}\left(\mathrm{SO}_{4}\right) \mathrm{OH}_{2}^{+} \\
& \equiv \mathrm{Fe}\left(\mathrm{SO}_{4}\right) \mathrm{H}^{2+}+\mathrm{H}_{3} \mathrm{AsO}_{3} \Rightarrow \equiv \mathrm{FeH}_{2} \mathrm{AsO}_{3}^{2+}+\mathrm{SO}_{4}^{2-}+2 \mathrm{H}^{+} \\
& \equiv \mathrm{Fe}\left(\mathrm{SO}_{4}\right) \mathrm{OH}_{2}^{+}+\mathrm{H}_{3} \mathrm{AsO}_{3} \Rightarrow \equiv \mathrm{FeH}_{2} \mathrm{AsO}_{3}^{2+}+\mathrm{SO}_{4}^{2-}+\mathrm{H}^{+}+\mathrm{H}_{2} \mathrm{O}
\end{aligned}
$$

$\equiv \mathrm{Fe}\left(\mathrm{SO}_{4}\right) \mathrm{O}^{-}+\mathrm{AsO}_{3}^{3-}+\mathrm{H}_{2} \mathrm{O} \Rightarrow \equiv \mathrm{FeAsO}_{3}+\mathrm{SO}_{4}^{2-}+2 \mathrm{OH}^{-}$

\subsection{Effects of the dosages of FBBS on As(III) adsorption}

To determine the optimized amount of the adsorbent, batch experiments were carried out with a group of dosages for FBBS and a fixed concentration of $\mathrm{As}(\mathrm{III})(5 \mathrm{mg} / \mathrm{L})$. Fig. 5 demonstrates that the removal efficiency of As(III) increased obviously with an increase in adsorbent dosages. After the reaction for $24 \mathrm{~h}$ with an initial $\mathrm{pH} 7$ at $\mathrm{T}=25^{\circ} \mathrm{C}$, the removal efficiency of As with a FBBS dosage of $2.0 \mathrm{~g} / \mathrm{L}$ could be higher than $90 \%$; and with a dosage of $6.0 \mathrm{~g} / \mathrm{L}$, could surpass $98 \%$. That is to say, the residual As was lower than $0.1 \mathrm{mg} / \mathrm{L}$, which could meet the discharge standards of pollutants for municipal wastewater treatment plants in China (GB18918-2002). Thus, the dosage of $6 \mathrm{~g} / \mathrm{L}$ for FBBS might be a good choice in the further pilot-scale studies. Additionally, FBBS may be not suitable to the treatment of the As-containing wastewater at very high levels $(>10 \mathrm{mg} / \mathrm{L})$, for a large dosage of adsorbent would increase the difficulty in the engineering application.

\subsection{Effects of coexisting anions on As(III) adsorption}

Coexisting anions with different concentrations are widely present in various kinds of wastewater, and they may interfere with the uptake of As through competitive adsorption. Fig. 6 illustrates the influences of carbonate, sulfate, chloride ion, and phosphate on the removal of As(III) by FBBS. It could be seen that sulfate and chloride ions had negligible influences on the removal of As(III). With the concentrations of carbonate increasing from 0 to 1 and $10 \mathrm{mM}$, the removal efficiency of $\mathrm{As}(\mathrm{III})$ decreased from $98.3 \%$ to $97.6 \%$ and $90.4 \%$. Among these anions, phosphate showed the most significant side effects on the removal of As(III) by FBBS. The removal efficiency was reduced to $78.9 \%$ at phosphate $=1 \mathrm{mM}$; and to $61.4 \%$ at phosphate $=10 \mathrm{mM}$. Fig. S5 shows that phosphate

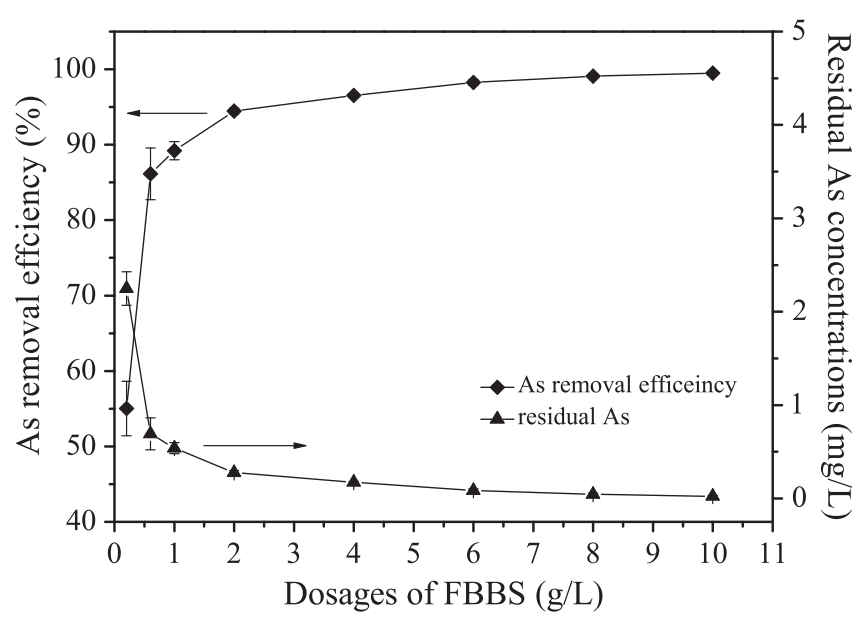

Fig. 5. Effects of varying FMBO dosages on the removal of As(III) by FBBS. (Experimental conditions: initial $\mathrm{As}(\mathrm{III})=5 \mathrm{mg} / \mathrm{L}, \quad \mathrm{pH}=7.0 \pm 0.2$, ion strength $=0.01 \mathrm{M} \mathrm{NaNO}$, agitation speed $=170 \mathrm{rpm}, \quad \mathrm{T}=25 \pm 1{ }^{\circ} \mathrm{C}$, reaction time $=24$ h.) 


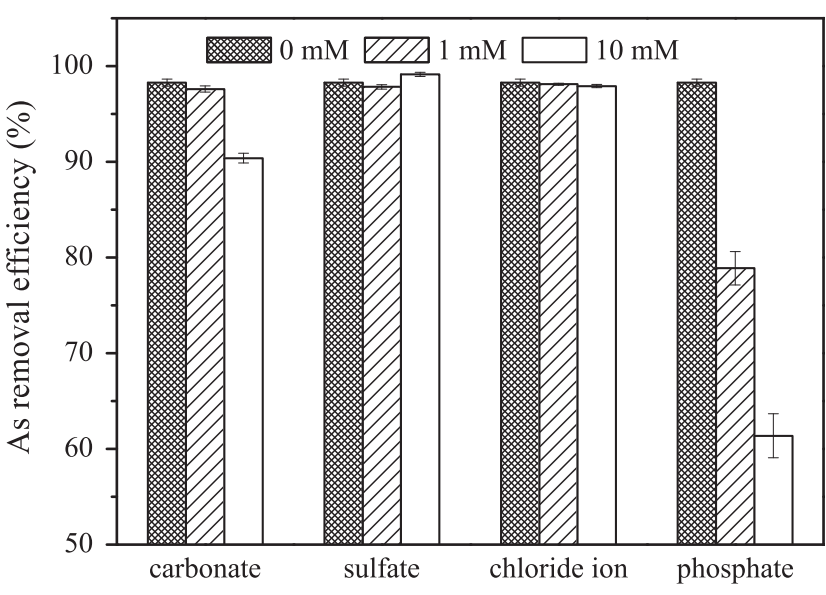

Fig. 6. Influences of carbonate, sulfate, chloride ion, and phosphate on the adsorption of $\mathrm{As}(\mathrm{III})$ by FBBS. (Experimental conditions: initial $\mathrm{As}(\mathrm{III})=5 \mathrm{mg} / \mathrm{L}$, adsorbent dosage $=6.0 \mathrm{~g} / \mathrm{L}, \mathrm{pH}=7.0 \pm 0.2$, ion strength $=0.01 \mathrm{M} \mathrm{NaNO}_{3}$, agitation speed $=170 \mathrm{rpm}, \mathrm{T}=25 \pm 1{ }^{\circ} \mathrm{C}$, reaction time $=24 \mathrm{~h}$.)

also had the strongest inhibition effects on the removal of $\mathrm{As}(\mathrm{V})$ by FBBS under the same experimental conditions.

Li et al. [12] investigated the removal of As(III) by FRS, and they also found that the interfering effects of phosphate on As removal are highest among several coexisting anions. Elemental phosphorus $(\mathrm{P})$ is located in the same main group with As, and phosphate shows similar chemical characteristics with As species. Thus, phosphate exhibits significant adverse effects on the adsorption of As mainly through the mechanisms such as competitive adsorption and charge diffusion [43]. Another possible reason for the adverse effect on adsorption is the formation of phosphate complexes with $\mathrm{Fe}(\mathrm{III})$, such as ferric dihydrophosphate $\left(\mathrm{Fe}\left(\mathrm{H}_{2} \mathrm{PO}_{4}\right)_{3}\right)$, which are more stable than the complexes formed by other ions $\left(\mathrm{Cl}^{-}, \mathrm{SO}_{4}^{2-}\right.$ and $\left.\mathrm{HCO}_{3}^{-}\right)$[44]. Because of the precipitation of $\mathrm{Fe}\left(\mathrm{H}_{2} \mathrm{PO}_{4}\right)_{3}(\mathrm{~s})$ that occurs in the adsorption process, the adsorption due to the uptake of amorphous Fe oxide is expected to be much lower than the process without phosphate ion.

\subsection{Analysis of FTIR and XPS spectra}

The spectroscopic analysis of FTIR and XPS was carried out to further investigate the adsorption mechanism of As(III) onto FBBS.

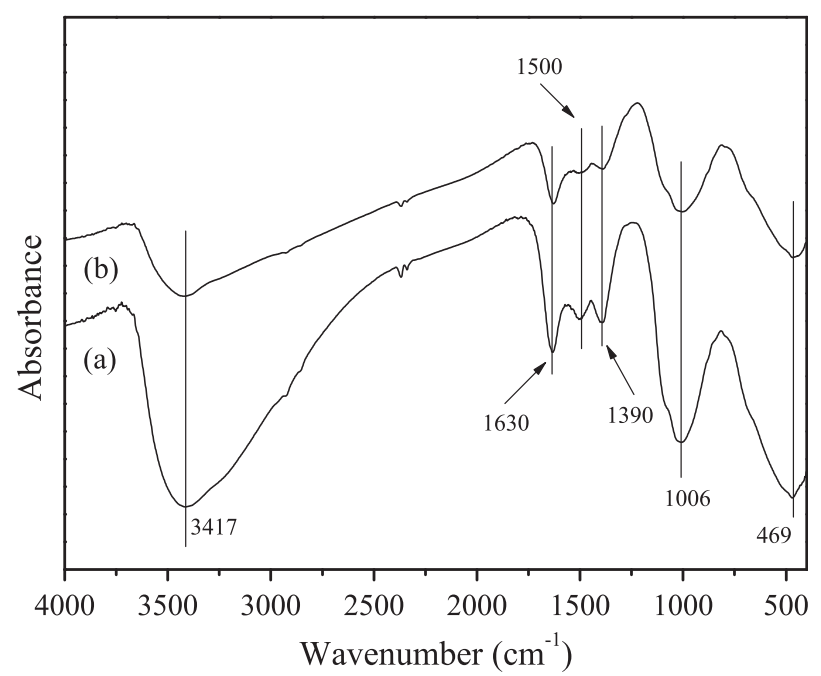

Fig. 7. The FTIR spectra of FBBS (a) before and (b) after the adsorption of As(III).

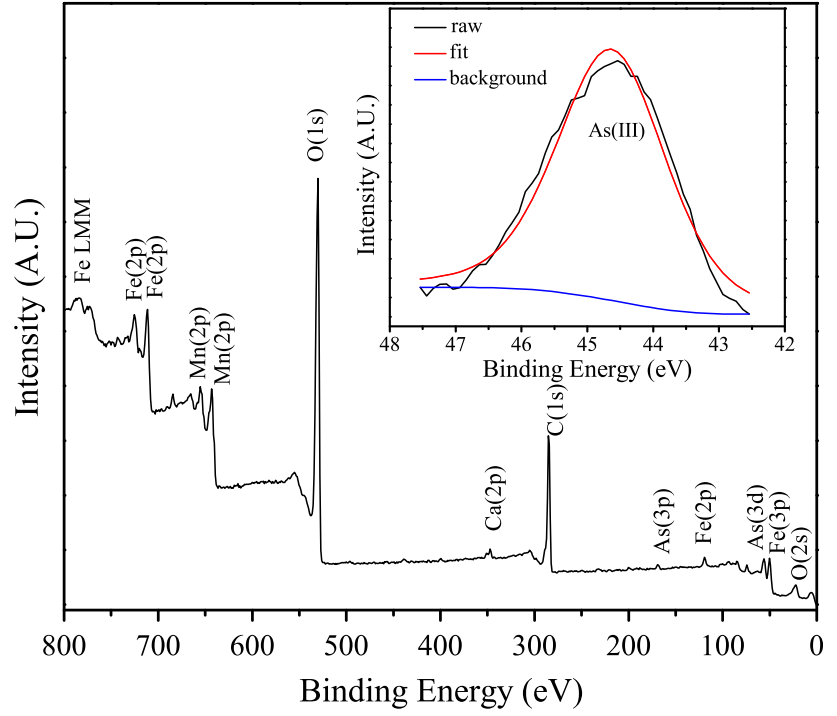

Fig. 8. The XPS spectra of wide scan and As3d of As-loaded FBBS.

Fig. 7 demonstrates the FTIR spectra of FBBS before and after the adsorption of $\mathrm{As}(\mathrm{III})$. The same sharp peak at $1630 \mathrm{~cm}^{-1}$ for the two curves could be attributed to the adsorbed water or water hydration within both fresh and As-loaded FBBS [45]. For fresh FBBS, the broad bands centered at $3417 \mathrm{~cm}^{-1}$ and $1006 \mathrm{~cm}^{-1}$ could be assigned to the bending vibration of hydroxyl groups $(-\mathrm{OH})$ on the surfaces of FBBS [45]. The peaks at $1390 \mathrm{~cm}^{-1}$ and $1496 \mathrm{~cm}^{-1}$ corresponds to $S=0$ stretching vibration [46], which indicates the presence of sulfate with FBBS. After the adsorption of As(III), a shape change of the peaks for $-\mathrm{OH}$ occurred, which implied that the surface hydroxyl groups on FBBS took part in the reaction with As(III). Meanwhile, the intensity of the peaks assigned $S=0$ decreased obviously, indicating that sulfate might be exchanged with arsenite in the adsorption process. In addition, the curve for Asloaded FBBS showed no occurrence of a new peak corresponding to $\mathrm{As}-\mathrm{OH}$ or $\mathrm{As}-\mathrm{O}-\mathrm{Fe}$ at $827 \mathrm{~cm}^{-1}$, suggesting that $\mathrm{As}(\mathrm{III})$ was not oxidized in the adsorption [47]. In contrast to $\mathrm{As}(\mathrm{V})$ adsorbed onto Fe oxides, it is difficult to detect the presence of adsorbed As(III) by the FTIR method $[47,48]$.

To prove the existence of As(III) onto FBBS, XPS analysis was conducted for the sample of FBBS reacted with As(III). Fig. 8 illustrates the wide scan XPS spectrum of FBBS after the adsorption of As(III). The disappearance of visible peaks for $S$ and the occurrence of new peaks for As were both observed, confirming the adsorption of As onto FBBS and the occurrence of the ion exchange between sulfate and arsenite. Moreover, Fig. 7 also exhibits the As3d core level of As-loaded FBBS, which binding energies was $44.5 \mathrm{eV}$. It has been reported that the values of the binding energy of the As3d core level in arsenic oxides were $44.3-44.5 \mathrm{eV}$ for As(III); and 45.2-45.6 eV for $\mathrm{As}(\mathrm{V})[49,50]$. Therefore, it can be consolidated that the oxidation state of $\mathrm{As}(\mathrm{III})$ was not changed during the adsorption process.

According to the aforementioned results, we proposed that the As(III) removal mechanisms might include ligand exchange, $\mathrm{Fe}(\mathrm{III})$ precipitation, and the adhesion to the surface hydroxyl groups, which could be illustrated in Fig. 9 .

\subsection{Desorption behaviors}

As-loaded solid residuals from adsorption operations are expected to be disposed of in landfills, where potential arsenic remobilization presents an obvious environmental concern. The TCLP is 


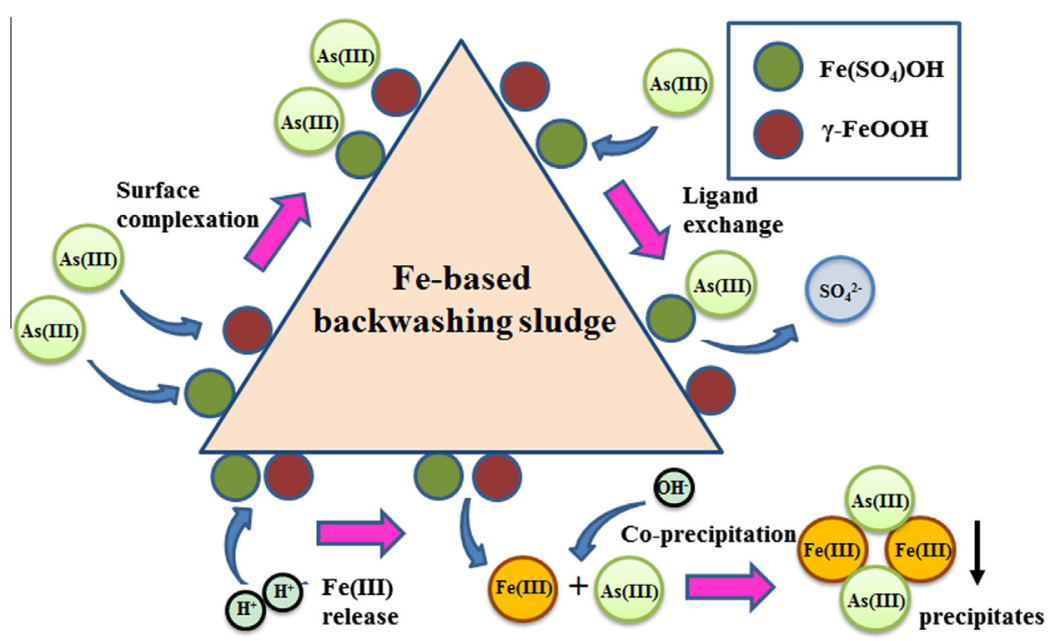

Fig. 9. The proposed removal mechanisms of As(III) using FBBS as an adsorbent.

designed to assess the potential and determine if the waste can be disposed in a non-hazardous landfill [51]. The As concentration in the leachate of As-loaded FBBS was determined to be $0.83 \mathrm{mg} / \mathrm{L}$, and it was far below the corresponding standard limit of $5 \mathrm{mg} / \mathrm{L}$ as being required by the TCLP procedures of USEPA [52]. This indicated that the FBBS after adsorbing As(III) can be landfilled without stabilization. After being landfilled, several factors may likely influence the release of As, including $\mathrm{pH}$, redox potential variations, anion exchange, interactions with natural organic matter (NOM), and biotransformation processes [53]. It was noted that the alkali or phosphate elution could be generated by the surface runoff or the wastewater discharge. To evaluate the effects of FBBS with adsorbed $\mathrm{As}(\mathrm{III})$ on underground water, we investigated the As desorption behaviors of As-loaded FBBS under different pH conditions and at various phosphate concentrations.

It is shown in Fig. 10 that the release of As was insignificant in a wide $\mathrm{pH}$ range from 3 to 9 . The corresponding ratios of As release were consistently below $0.5 \%$ from $\mathrm{pH} 3$ to $\mathrm{pH} 9$, indicating that the As-loaded FBBS was safe under acidic, neutral and slightly alkaline

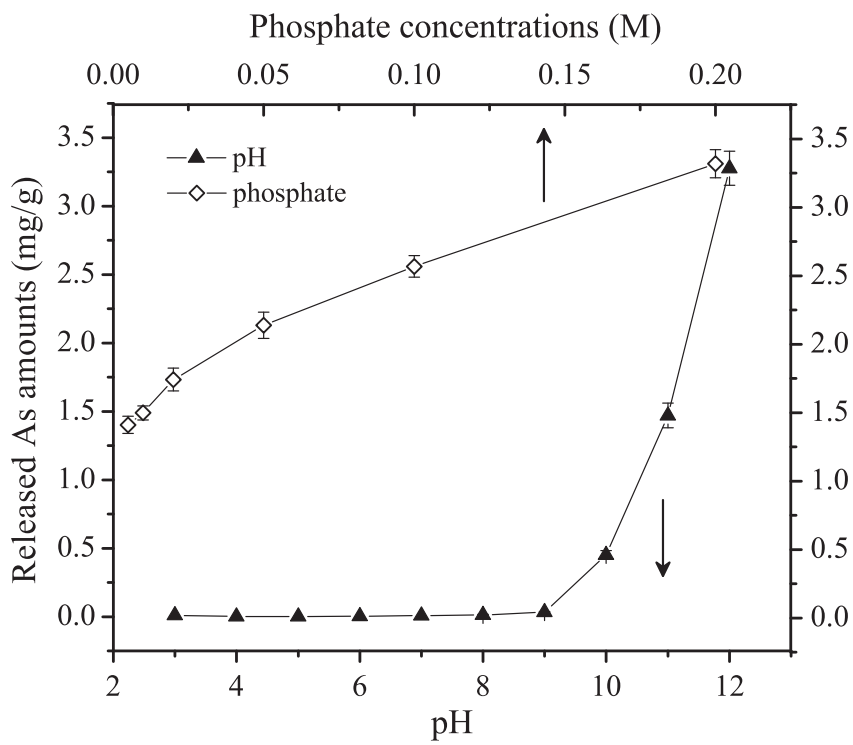

Fig. 10. Desorption of As from As-loaded FBBS $\left(q_{e}=7.7 \mathrm{mg} / \mathrm{g}\right)$ using solutions with various $\mathrm{pH}$ (without phosphate) or different phosphate concentrations (at $\mathrm{pH} 7.0$ ) (Experimental conditions: sample dose $=0.6 \mathrm{~g} / \mathrm{L}$, ion strength $=0.01 \mathrm{M} \mathrm{NaNO}$, agitation speed $=170 \mathrm{rpm}, \mathrm{T}=25 \pm 1^{\circ} \mathrm{C}$, reaction time $=24 \mathrm{~h}$.). conditions. The amounts of As desorption increased with the elevated $\mathrm{pH}$ at above $\mathrm{pH} 9$, and it was observed to be $3.28 \mathrm{mg} / \mathrm{g}$ at $\mathrm{pH}$ 12. It is inferred that As-FBBS may be hazardous under strong alkaline conditions, though it passed the TCLP test. Moreover, Fig. 10 also shows that the amounts of desorbed As were elevated dramatically once the solution contained phosphate anions. The amounts of As desorption were increased from 1.41 and $3.32 \mathrm{mg} /$ $\mathrm{g}$ as the phosphate concentrations increased from 0.005 to $0.2 \mathrm{M}$ (at pH 7.0). It could be due to that the bonding between the active sites and the adsorbed As was vulnerable at high phosphate concentrations. Generally, the leachate solution of As-loaded FBBS may cause secondary pollution under either strong alkaline or high phosphorus conditions (phosphate $>0.05 \mathrm{M}$ ). In these cases, other effective measures should be taken to minimize As release and avoid the risks of secondary pollution.

\section{Conclusions}

This study demonstrates that FBBS, a by-product of Fe-removal plants can be used as a cost-effective adsorbent for As(III) in aqueous solutions. The analysis results of EDS, XPS, XRF, and acid digestion confirmed that the effective components within FBBS for $\mathrm{As}(\mathrm{III})$ removal are $\gamma$-FeOOH and $\mathrm{Fe}\left(\mathrm{SO}_{4}\right) \mathrm{OH}$. The $\mathrm{pH}_{\mathrm{ZPC}}$ value was around 7.7 according to the zeta potential results. The adsorption equilibrium for As(III) could be reached with $18 \mathrm{~h}$. The adsorption kinetics data could be well fitted by both the Elovich model and the Power model, which was in accordance with the heterogeneous material systems of FBBS. The maximum adsorption amount of As(III) was determined to be $59.7 \mathrm{mg} / \mathrm{g}$ (initial $\mathrm{As}(\mathrm{III})=1$ $120 \mathrm{mg} / \mathrm{L}$ ) according to the Langmuir model at $\mathrm{pH}=7.0$, which was greater than most of other low-cost adsorbents. Additionally, the adsorption of $\mathrm{As}$ (III) is an ethermodomic process, and the maximum uptake could be increased to $69.8 \mathrm{mg} / \mathrm{g}$ at $\mathrm{T}=45^{\circ} \mathrm{C}$. The removal efficiency of As(III) was highly dependent on solution $\mathrm{pH}$, and the optimal $\mathrm{pH}$ was observed at around $\mathrm{pH}$ 8.0. The uptake of $\mathrm{As}(\mathrm{III})$ by FBBS is mainly controlled by the adhesion to the surface hydroxyl groups, $\mathrm{Fe}(\mathrm{III})$ precipitation, and the ligand exchanges between As species and sulfate. It is noted that phosphate has significant side-effects on the As(III) removal through competitive adsorption. Moreover, the desorption results presents that the release of As from As-loaded FBBS could occur at strong alkali or high phosphate concentrations, inferring that the safe disposal of this waste should be considered to avoid secondary pollution in these cases. Despite these disadvantages, FBBS 
still has great potential to be a promising low-cost adsorbent for the removal of $\mathrm{As}(\mathrm{III})$ from high-arsenic wastewater.

\section{Acknowledgements}

This work was supported by the Natural Science Foundation of China (Grant No. 51208415), the key project of National "863" High-tech R\&D Program of China (Grant No. 2012AA062604), China Postdoctoral Science Foundation (Grant No. 2012M511986), and Research Fund for the Doctoral Program of Higher Education of China (20126120120005).

\section{Appendix A. Supplementary material}

Supplementary data associated with this article can be found, in the online version, at http://dx.doi.org/10.1016/j.cej.2013.04.076.

\section{References}

[1] M.F. Hughes, Arsenic toxicity and potential mechanisms of action, Toxicol. Lett 133 (1) (2002) 1-16.

[2] B.K. Mandal, K.T. Suzuki, Arsenic round the world: a review, Talanta 58 (1) (2002) 201-235.

[3] D. Mohan, C.U. Pittman Jr., Arsenic removal from water/wastewater using adsorbents-A critical review, J. Hazard. Mater. 142 (2007) 1-53.

[4] C.H. Weng, Y.C. Wu, Potential Low-cost Biosorbent for Copper Removal: Pineapple Leaf Powder, J. Environ. Eng. ASCE 138 (2012) 286-292.

[5] S. Jellali, M.A. Wahab, R.B. Hassine, A.H. Hamzaoui, L. Bousselmi, Adsorption characteristics of phosphorus from aqueous solutions onto phosphate mine wastes, Chem. Eng. J. 169 (2011) 157-165.

[6] B. Kayranli, Adsorption of textile dyes onto iron based waterworks sludge from aqueous solution; isotherm, kinetic and thermodynamic study, Chem. Eng. J. 173 (2011) 782-791.

[7] E. Diamadopoulos, S. Loannidis, G.P. Sakellaropoulos, As(V) removal from aqueous solutions by fly ash, Water Res. 27 (1993) 1773-1777.

[8] Y.R. Li, F.S. Zhang, F.R. Xiu, Arsenic(V) removal from aqueous system using adsorbent developed from a high iron-containing fly ash, Sci. Total. Environ. 407 (2009) 5780-5786.

[9] S.R. Kanel, H. Choi, J.Y. Kim, S. Vigneswaran, W.G. Shim, Removal of arsenic(III) from groundwater using low-cost industrial by-products-blast furnace slag Water Qual. Res. J. Can. 41 (2006) 130-139.

[10] H.S. Altundogan, S. Altundogan, F. Tumen, M. Bildik, Arsenic removal from aqueous solutions by adsorption on red mud, Waste Manage. 20 (2000) 761767.

[11] H.S. Altundogan, S. Altundogan, F. Tumen, M. Bildik, Arsenic adsorption from aqueous solutions by activated red mud, Waste Manage. 22 (2002) 357-363.

[12] Y.R. Li, J. Wang, Z.K. Luan, Z. Liang, Arsenic removal from aqueous solution using ferrous based red mud sludge, J. Hazard. Mater. 177 (2010) 131-137.

[13] C.M. Konstantinos, S. Dibyendu, D. Rupali, Evaluating a drinking-water waste by-product as a novel sorbent for arsenic, Chemosphere 64 (2006) 730-741.

[14] C. Namasivayam, S. Senthilkumar, Removal of arsenic(V) from aqueous solution using industrial solid waste: adsorption rates and equilibrium studies, Ind. Eng. Chem. Res. 37 (1998) 4816-4822.

[15] E.G. Dion, M. Mamata, B.I. Touma, A. Shashi, S. Pritam, Iron and aluminium based adsorption strategies for removing arsenic from water, J. Environ. Manage. 92 (2011) 3011-3022.

[16] A. Bhatnagar, M. Sillanpää, Utilization of agro-industrial and municipal waste materials as potential adsorbents for water treatment-A review, Chem. Eng. J. 157 (2010) 277-296.

[17] A.S.C. Chen, W.E. Condit, B.J. Yates, L. Wang, Arsenic Removal from Drinking Water by for Iron Removal Small System, Report EPA 600-R-10-033, USEPA, Washington DC, 2010.

[18] K. Wu, T. Liu, J.M. Peng, Adsorption behaviors of arsenic(V) onto Fe-based backwashing sludge produced from Fe(II)-removal plants, Appl. Mech. Mater. 295-298 (2013) 1321-1326.

[19] P.L. Smedley, D.G. Kinniburgh, A review of source, behaviors and distribution of arsenic in natural waters, Appl. Geochem. 17 (5) (2002) 517-568.

[20] L. Vega, M. Styblo, R. Patterson, W. Cullen, C. Wang, D. Germolec, Differential effects of trivalent and pentavalent arsenicals on cell proliferation and cytokine secretion in normal human epidermal keratinocytes, Toxicol. Appl. Pharmacol. 172 (2001) 225-232.

[21] W. Driehaus, R. Seith, M. Jekel, Oxidation of arsenite(III) with manganese oxides in water treatment, Water Res. 29 (1) (1994) 297-305.

[22] US Environmental Protection Agency, Toxicity Characteristics Leaching Procedure, US EPA, Washington DC, 1999, pp. 11798.

[23] Z.Y. Hseu, Z.S. Chen, C.C. Tsai, C.C. Tsui, S.F. Cheng, C.L. Liu, H.T. Lin, Digestion methods for total heavy metals in sediments and soils, Water Air Soil Poll. 141 (2002) 189.
[24] T.D. Glotch, M.D. Kraft, Thermal transformations of akaganéite and lepidocrocite to hematite: assessment of possible precursors to Martian crystalline hematite, Phys. Chem. Mineral. 35 (2008) 569-581.

[25] J.F. Moulder, W.F. Stickle, P.E. Sobol, K.D. Bomben, Handbook of X-ray Photoelectron Spectroscopy, Norwalk: Perkin-Elmer, 1992, pp: 80-81.

[26] W. Rudzinski, W.A. Steele, G. Zgrablich, Equilibria and Dynamics of Gas Adsorption on Heterogeneous Solid Surfaces, Elsevier, Amsterdam, 1996.

[27] W.J. Weber Jr, J.C. Morris, Kinetics of adsorption on carbon from solution, J. Sanitary Eng. Div. Proceed. Am. Soc. Civ. Eng 89 (1963) 31-59.

[28] M.J.D. Low, Kinetics of chemisorption of gases on solids, Chem. Rev. 60 (1960) 267-312.

[29] G.S. Zhang, J.H. Qu, H.J. Liu, R.P. Liu, R.C. Wu, Preparation and evaluation of a novel Fe-Mn binary oxide adsorbent for effective arsenite remove, Water Res. 41 (2007) 1921-1928.

[30] A.O. Babatunde, Y.Q. Zhao, Equilibrium and kinetic analysis of phosphorus adsorption from aqueous solution using waste alum sludge, J. Hazard. Mater. 184 (2010) 746-752.

[31] X.Y. Song, Y.Q. Pan, Q.Y. Wu, Z.H. Cheng, W. Ma, Phosphate removal from aqueous solutions by adsorption using ferric sludge, Desalination 280 (2011) 384-390.

[32] I. Langmuir, The adsorption of gases on plane surfaces of glass, mica and platinum, J. Am. Chem. Soc. 40 (1918) 1361-1403.

[33] H.M.F. Freudlich, Ünber die adsorption in lösungen, Phys. Chem 57 (A) (1906) 385-470. Leipzig.

[34] H.T. Li, M.C. Xu, Z.Q. Shi, B.L. He, Isotherm analysis of phenol adsorption on polymeric adsorbents from nonaqueous solution, J. Colloid Interf. Sci. 271 (2004) 47-54.

[35] J.W. Lim, Y.Y. Chang, J.K. Yang, S.M. Lee, Adsorption of arsenic on the reused sanding waste calcined at different temperatures, Colloid. Surf. A Physicochem Eng. Aspects 345 (2009) 65-70.

[36] X.G. Meng, S. Bang, G.P. Korfiatis, Effects of silicate, sulfate, and carbonate on arsenic removal by ferric chloride, Water Res. 34 (4) (2000) 1255-1261.

[37] W. Stumm, Chemistry of the Solid-Water Interface, John Wiley \& Sons, Inc., 1992.

[38] K.P. Raven, A. Jain, R.H. Loeppert, Arsenite and arsenate adsorption on Fe oxyhydroxide: kinetics, equilibrium, and adsorption envelopes, Environ. Sci. Technol. 32 (1998) 344-349.

[39] F.S. Zhang, H. Itoh, Iron oxide-loaded slag for arsenic removal from aqueous system, Chemosphere 60 (3) (2005) 319-325.

[40] G.S. Zhang, H.J. Liu, J.H. Qu, W. Jefferson, Arsenate uptake and arsenite simultaneous sorption and oxidation by Fe-Mn binary oxides: Influence of $\mathrm{Mn} / \mathrm{Fe}$ ratio, $\mathrm{pH}, \mathrm{Ca}^{2+}$, and humic acid, J. Colloid. Interf. Sci. 366 (1) (2012) $141-146$.

[41] E.D. Burton, R.T. Bush, S.G. Johnston, K.M. Watling, R.K. Hocking, L.A. Sullivan, G.K. Parker, Sorption of arsenic(V) and arsenic(III) to schwertmannite, Environ. Sci. Technol. 43 (2009) 9202-9207.

[42] Y.H. Liao, J.R. Liang, L.X. Zhou, Adsorptive removal of As(III) by biogenic schwertmannite from simulated As-contaminated groundwater, Chemosphere 83 (2011) 295-301.

[43] S. Goldberg, Competitive adsorption of arsenate and arsenite on oxides and clay minerals, Soil. Sci. Soc. Am. J. 66 (2002) 413.

[44] C.H. Weng, Y.T. Lin, C.K. Chang, N. Liu, Decolourization of direct blue 15 by Fenton/ultrasonic process using a zero-valent iron aggregate catalyst, Ultrason. Sonochem. 20 (3) (2013) 970-977.

[45] Y. Zhang, M. Yang, X. Dou, H. He, D. Wang, Arsenate adsorption on an Fe-Ce bimetal oxide adsorbent: role of surface properties, Environ. Sci. Technol. 39 (2005) 7246-7253.

[46] P.L. Anto, R.J. Anto, H.T. Varghese, C.Y. Panicker, D. Philipe, A.G. Brolof, FT-IR, FT-Raman and SERS spectra of anilinium sulfate, J. Raman Spectrosc. 40 (2009) 1810-1815.

[47] S. Goldberg, C.T. Johnston, Mechanisms of arsenic adsorption on amorphous oxides evaluated using macroscopic measurements, vibrational spectroscopy, and surface complexation modeling, J. Colloid Interf. Sci. 234 (1) (2001) 204216.

[48] Z.M. Ren, G.S. Zhang, J.P. Chen, Adsorptive removal of arsenic from water by an iron-zirconium binary oxide adsorbent, J. Colloid Interf. Sci. 358 (2011) 230237.

[49] H.W. Nesbitt, G.W. Canning, G.M. Bancroft, XPS study of reductive dissolution of $7 \AA$-Birnessite by $\mathrm{H}_{3} \mathrm{AsO}_{3}$, with constraints on reaction mechanism, Geochim. Cosmochim. Acta. 62 (1998) 2097-2110.

[50] S. Ouvrard, P. de Donato, M.O. Simonnot, S. Begin, J. Ghanbaja, M. Alnot, Y.B. Duval, F. Lhote, O. Barres, M. Sardin, Natural manganese oxide: combined analytical approach for solid characterization and arsenic retention, Geochim. Cosmochim. Acta 69 (2005) 2715-2724.

[51] A. Ghosh, M. Mukiibi, W. Ela, TCLP underestimates leaching of arsenic from solid residuals under landfill conditions, Environ. Sci. Technol. 38 (2004) 4677-4682.

[52] US Environmental Protection Agency, Hazardous Waste Management System; Identification and Listing of Hazardous Waste; Toxicity Characteristics Revisions; Final Rule, Federal Register, USEPA, Washington DC, 1990, pp. 11798-11877.

[53] M. Li, Arsenic Leaching From Spent Adsorbents Under Landfill Conditions, Doctor thesis, The Ohio State University, 2009, pp: 42-52. 